\title{
BASIC ASPECTS FOR THE ECOLOGICAL RESTORATION OF URBAN WATER COURSES
}

\author{
Ulrike BART *, Clemens GUMPINGER ** \\ and Christian SCHEDER ***
}

* Aquatic Biology and Engineering, Gärtnerstraße 9, Wels, Austria, A-4600, bart@blattfisch.at

** Aquatic Biology and Engineering, Gärtnerstraße 9, Wels, Austria, A-4600, gumpinger@blattfisch.at

*** Aquatic Biology and Engineering, Gärtnerstraße 9, Wels, Austria, A-4600, scheder@blattfisch.at

DOI: 10.1515/trser-2015-0054

KEYWORDS: revitalisation, habitat restoration, urban floodplains, restructuration, model, fine sediments, longitudinal continuum, Austria, Water Framework Directive, ecological status.

\section{ABSTRACT}

Due to the fact that urban water courses provide precious natural and recreational areas within urban surroundings and that they contribute to an increase in quality of life, they have gained more and more importance in recent years. The restoration and planning of urban water bodies pose an enormous challenge, because most of them are in a poor ecological and structural state.

This paper deals with the questions and problems concerning the topic and presents basic aspects for the ecological restoration of urban water courses.

ZUSAMENFASSUNG: Grundsätzliche Aspekte für die ökologische Wiederherstellung urbaner Fließgewässer.

In den letzen Jahren kommt den urbanen Stadtgewässern eine immer größere Bedeutung zu, da sie wertvolle städtische Natur-, Freizeit- und Erholungsräume zur Verfügung stellen, die zur Steigerung der Lebensqualität beitragen. Die Sanierung und Entwicklung derartiger Gewässer stellt eine große Herausforderung dar, denn die meisten innerstädtischen Gewässer befinden sich in einem unbefriedigenden ökologischen und strukturellen Zustand.

Die vorliegenden Arbeit beschäftigt sich mit den Fragestellungen und Problemen dieser Thematik und zeigt modellhaft die wichtigsten Aspekte für die ökologische Sanierung urbaner Fließgewässer. urbane.

REZUMAT: Aspecte de bază pentru reconstrucţia ecologică a cursurilor de apă

Datorită faptului că furnizează zone naturale preţioase şi de recreere în cadrul aşezărilor urbane, contribuind la o creştere a calităţii vieţii, cursurile de apă urbane au câştigat o importanţă din ce în ce mai mare în ultimii ani. Restaurarea şi planificarea corpurilor de apă urbane reprezintă o provocare enormă, datorită faptului că o mare parte dintre ele sunt într-o stare ecologică şi structurală precară.

Această lucrare se ocupă cu întrebările şi problemele referitoare la acest subiect şi prezintă aspecte de bază pentru refacerea ecologică a cursurilor de apă urbane. 


\section{INTRODUCTION}

The morphology of natural rivers is characterised by the dynamics of the stream flow. The general appearance of a water course, its banks and its surrounding area are subject to a constant change. This dynamic balance leads to a continuous rearrangement of structures within the water course, whereas the quantity of structures remains mainly constant. The riparian and aquatic flora and fauna is adapted to this permanent change, some species even rely on it.

Due to the industrialisation and increasing settlement many rivers have been channelled and regulated. This degradation has led to a massive disturbance of the biological system and the groundwater balance. Many river sections have turned into structureless water channels without any natural dynamics. Many specialised animal and plant species lack habitats and fade away gradually, whereas species which are insensitive to environmental influence stand to benefit from this fact and proliferate. (Gumpinger and Scheder, 2008)

Urban water courses are especially affected by the degradation and homogenisation described above. The shortage of space on the one hand and the increasing demands of area for infrastructure and site utilisation on the other hand have led to a constant subtraction of space originally engaged by water courses (Fig. 1). Due to flood protection measures and the misguided belief that rivers must be controlled by means of technical structures, many partly irreparable modifications have been made. Ecological issues were disregarded and water courses were reduced to the function of a water channel. In the late 20th century a change of ideology took place and guidelines like the Water Framework Directive (WFD; European Commission, 2000) support this process.

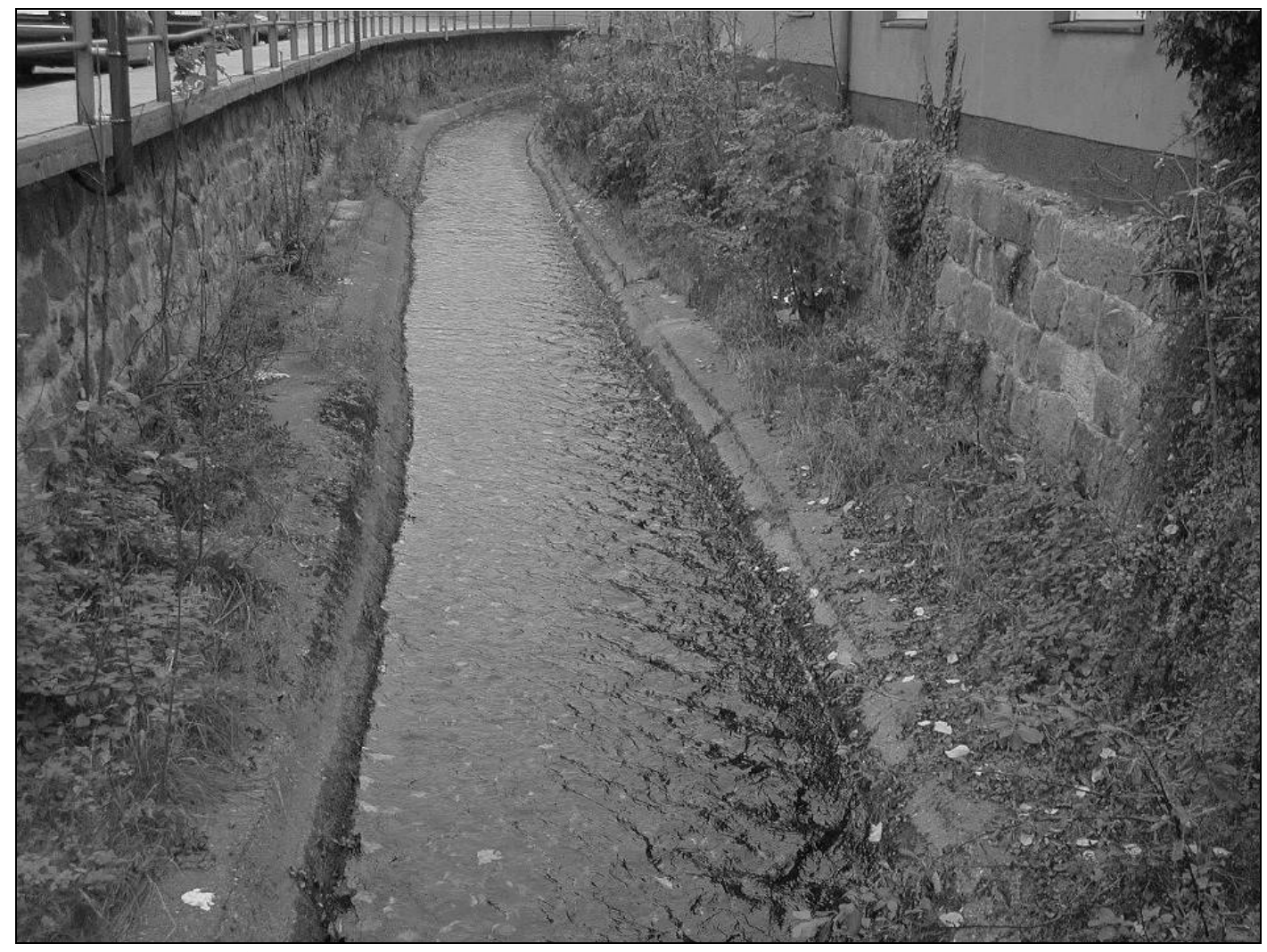

Figure 1: The Breitsach Brook in Ried im Innkreis (Austria). 


\section{Common problems of urban water courses}

Urban water courses and their floodplains are affected by intensive anthropogenic use; that is why most of them are confronted with similar problems. Almost all channels are straightened, narrowed and lowered. Beds and banks are frequently constructed and they lack natural structures which ought to be habitats or stepping stones for the aquatic and riparian fauna. Man-made different barriers interrupt the longitudinal river continuum (Fig. 2) and affect the natural dynamic of discharge and also the bed load. In the worst case water courses are actually piped (Fig. 3) and therefore deprived of any ecological function.

Expanded floodplains are extremely rare because of the lack of space, and even narrow riparian groves have been reduced to scattered and isolated structures that have lost their original function. The lateral connectivity between the water course and its surroundings is interrupted, which leads to an enormous loss of structure and habitats. Intact aquatic and semi-aquatic ecosystems are composed of a mosaic of small-scale habitats in different stages of development. There are many interactions between the ecosystemcomplexes and furthermore between the particular habitats (Ulmann and Peter, 1994) that are missing in regulated channels. Natural river banks and riparian woods offer a large number of ecological niches and precious back-up habitats or refuge areas for threatened species and would be necessary especially in urban areas, where there is mostly a total lack of those structures.

The restoration of urban water courses offers a significant high ecological potential, therefore a professional appropriate planning is highly necessary to achieve the maximum benefits.

Unprofessional restoration can easily lead to monotonous, ecologically worthless areas with low biodiversity, even if they look intact in the eyes of a non-professional. Especially in urban areas the appearance of landscapes is important because of its health-related quality and function of recovery for human beings. A professional planner must be able to consider both the ecological and human demands.

Flood protection is one of the main topics in urban areas. As mentioned above, floodplains have been reduced to a minimum; and consequently so have the natural potential of retention. This fact leads to higher discharges that are intensified still by the enforced runoff from sealed soil surfaces. 


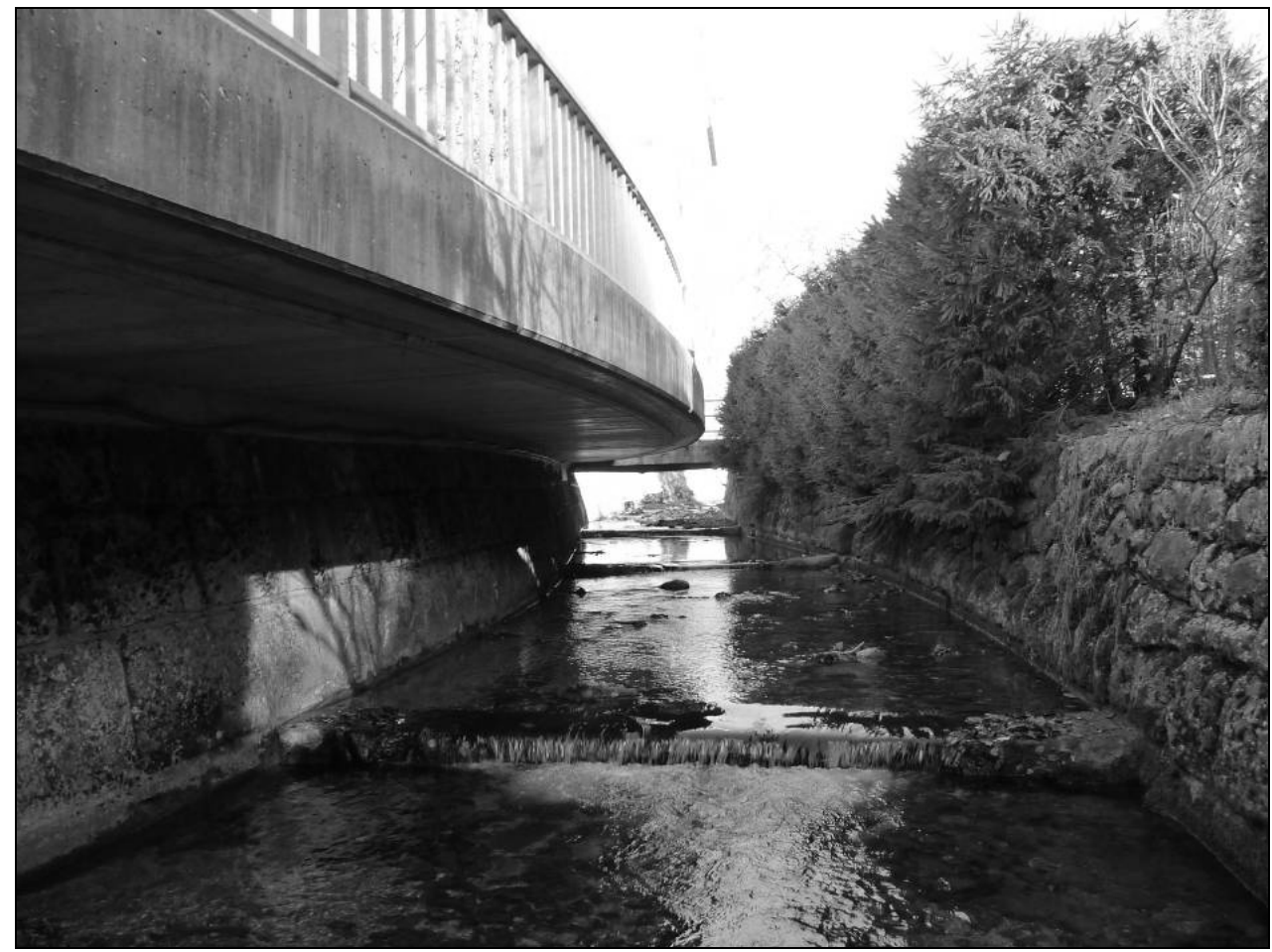

Figure 2: The Sulzbach Brook nearby Bad Ischl is an example for the missing longitudinal connectivity in water courses.

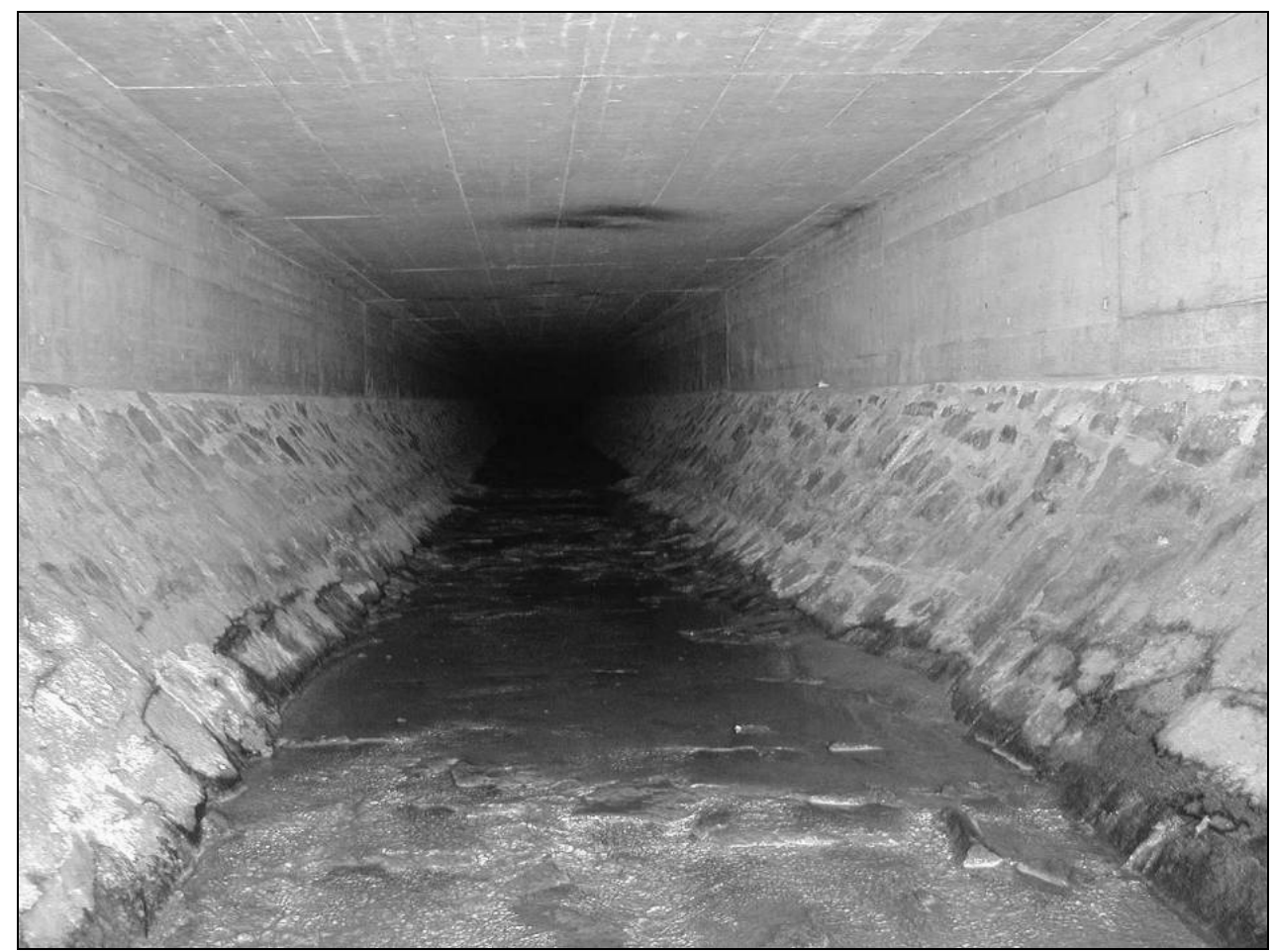

Figure 3: The Schweinbach Brook as an example for a tubed water course. 


\section{Ecological considerations on the restoration of urban water courses}

Due to the lack of space in the surroundings of urban water courses many compromises have to be accepted; an entire ecological restoration is hardly ever possible. Infrastructure, canal systems or ductings, tighten the possibilities for a comprehensive restoration because of their expensive relocation.

The first step in planning a restoration is the elaboration of a model for the water course. In the model development targets are defined in order to implement them by means of concrete concepts and reconstruction measures. First of all, a visionary model is derived from the original state, which means a situation unaffected by mankind. In the operational model that follows, anthropogenic conditions are considered and principles of conception that can be obtained under these conditions are developed. For the definition of the operational model fish core species, aerial photographs, old maps and historical reports are used. All this information is merged by an expert in order to achieve an archetype for the water course and to devise the main aims for its development. Below, the most frequently defined aims are listed:

- $\quad$ establishment of a water corridor (= active channel) and a low water channel;

- restoral of the typical stream course;

- increase of the diversity of structures and habitats;

- restoration of the longitudinal continuum;

- increase of retention and flood protection;

- reduction of fine sediments and sediment deficits;

- enhancement of the connection between water and riparian areas.

Establishment of a water corridor (= active channel) and a low water channel

Depending on the type and size of the water course, the corridor conform to the model can be quite wide (up to several hundred meters). Unfortunately, the establishment of such a corridor is illusory and so the existing profiles can only be widened as far as the neighbouring land-use allows.

Within this newly established corridor the low water channel should be able to move freely. The course of the low water channel is set roughly by placing structural elements (rootstocks, trunks, and stones, etc.) and gravel banks at appropriate positions in the channel bed. By lowering the land area in the corridor, many waterlogged zones are created, which are very important for the semi-aquatic fauna. In the case of increased discharges the corridor offers enough space for the riskless runoff of the water masses.

\section{Restoral of the typical stream course}

One of the most important measures concerning restoration is the removal of technical control structures in beds and banks and the insertion of natural sediments and wooden or stony structural elements (Figs. 4 and 5). The removal of inflexible technical control structures raises the potential for the development of a more dynamic water course. By integrating structural elements, the effect can be enhanced furthermore. 


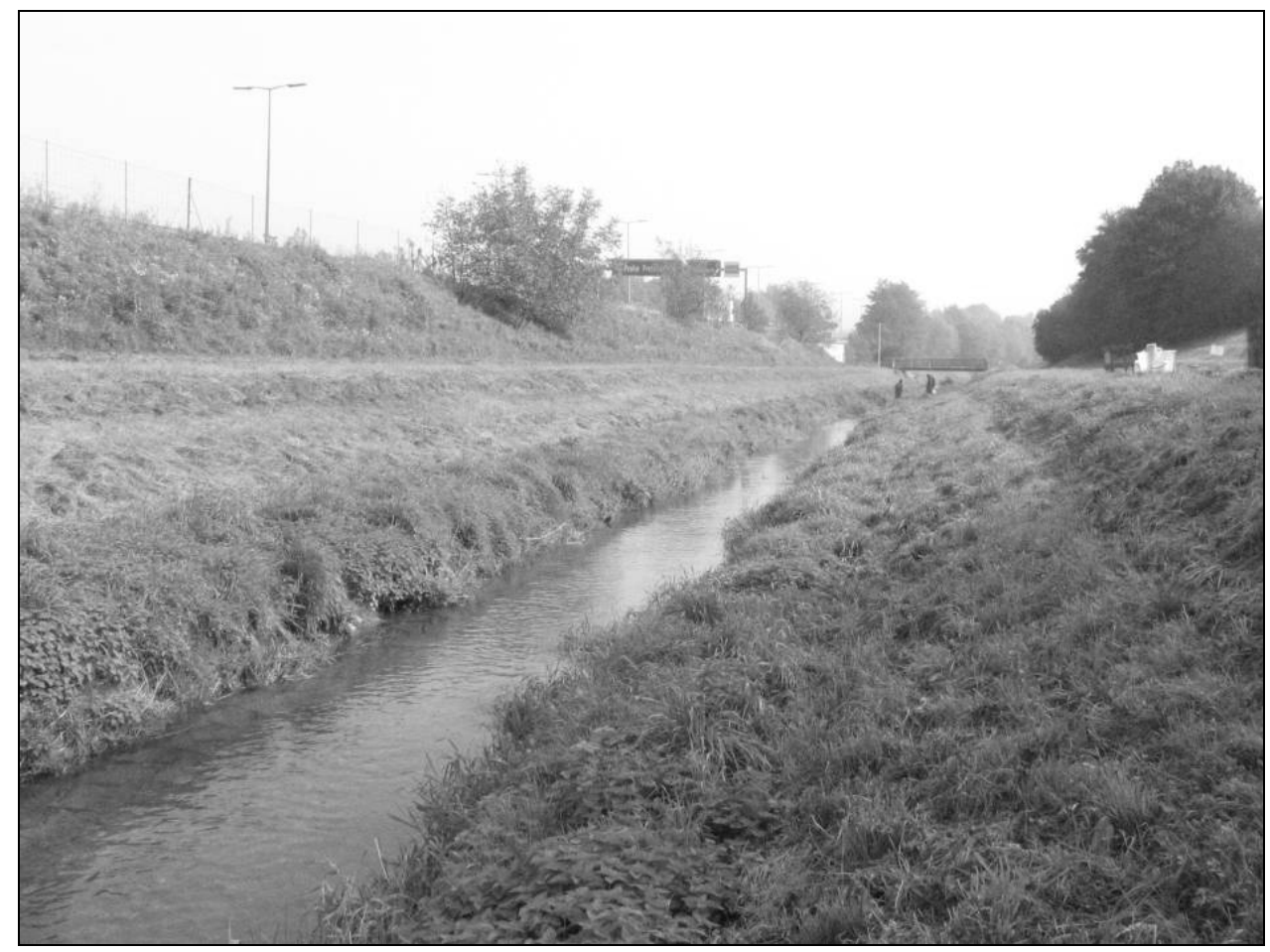

Figure 4: An artificial water course in Linz called "Urfahraner Sammelgerinne" before the restoration. The technical control structures that reach from the bed to the upper edge of the banks are not visible as they are covered with soil and vegetation.

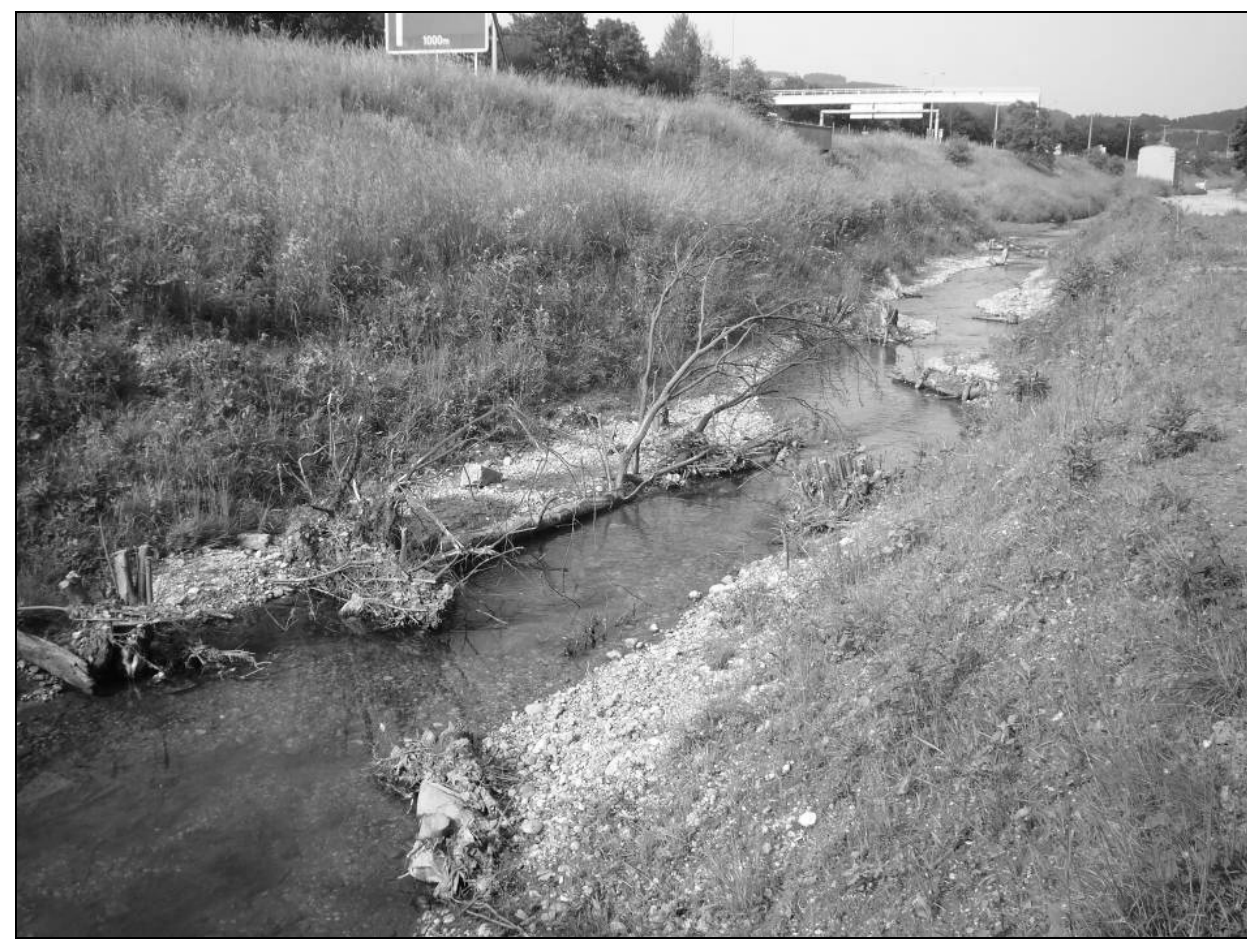

Figure 5: The "Urfahraner Sammelgerinne” in Linz after the restoration. 


\section{Increase of the diversity of structures and habitats}

Increasing the diversity of structures and habitats is important for the water course as well as for its surroundings. The development of structures and habitats in the water course is supported by a nature-like course and the insertion of structural elements. These elements have two functions. On the one hand they direct the flow and on the other hand they increase the diversity of structures. They represent natural materials like rootstocks, trunks, trees and roughly laid boulders. Stones are only used if it they conform to the model. Depending on their position and size structural elements induce sedimentation or erosion in the bed and banks, and thereby raise the diversity of structures and habitats.

\section{Restoration of the longitudinal continuum}

The longitudinal continuum is one of the most important criteria for an intact water course. Nearly all aquatic organisms migrate within the river system. Especially fish, but also benthic invertebrates require different biotopes and habitats during different developmental stages. In the majority of cases, man-made barriers inhibit migration and at worst even cut off the genetic exchange between different populations. In fish species, especially medium distance migrants like barbel (Barbus barbus), nase (Chondrostoma nasus) and Danube salmon (Hucho hucho) are heavily affected. But also short distance migrating fish like grayling (Thymallus thymallus), brown trout (Salmo trutta) or chub (Squalius cephalus) are impaired by the disruption of the longitudinal continuum.

\section{Reduction of fine sediments and sediment deficits}

In addition to enabling the longitudinal migration for aquatic organisms, the unhindered transportation of water and sediments must be guaranteed. Many water courses suffer from a lack of coarse sediments in downstream stretches, as gravel is retained by transverse constructions in upstream reaches. Due to this fact the proportion of fine sediments and the tendency of bed erosion increase. Fine sediments are characterised as particles smaller than $0.02 \mathrm{~mm}$ and show a high proportion of clay, silt and organic material. High impacts of fine sediments cause a clogging of the hyporheic interstitial, which leads to a shortage of oxygen in the pore-system, the most important habitat for the benthic fauna and for the fish reproduction. The clogging finally results in the destruction of the interstitial biocoenosis.

There are two possibilities for dealing with the problem of fine sediments. An effective way is the prevention of the input of fine sediments. Many water courses lack shelter belts or riparian woods, which assume the role of buffers or filters in landscapes. Due to this deficit, a constant and diffuse load of fine sediments is transported into watercourses by wind, rain and intensive agricultural farming. The establishment of riparian woods is one of the most important measures because they regulate the exchange and spreading rates of chemical compounds between terrestrial and aquatic systems. On the one hand they are mechanical filters for air-borne fine material and on the other hand they function as a biological filter by absorbing nutrients from the soil. Furthermore, the vegetation stabilises the banks and prevents them from being eroded (Zalewski and Wagner-Lotwowska, 2004).

A reduction of the fine sediment load can also be achieved by increasing the stream velocity. This can be obtained by augmenting the gradient of the river bed, by restricting the profile or by increasing the flow rate. In most cases, the restriction of the profile is the only practicable possibility. The Venturi effect states that if a moving fluid passes through a constriction, its velocity increases. Such a constriction can be achieved by placing elements like rootstocks, trunks, trees or boulders (Figs. 6 and 7) at appropriate positions. When the stream velocity is increased at these positions, the transportation of fine sediments is enhanced. 
In urban areas the enhancement of the flow velocity is the most effective strategy. As the fine sediment loads often originate from upstream agrarian areas, the restriction of the profile is more useful and practicable than the establishment of a buffer in form of a riparian grove. Nevertheless, bushes and trees in the riparian areas are fundamental.

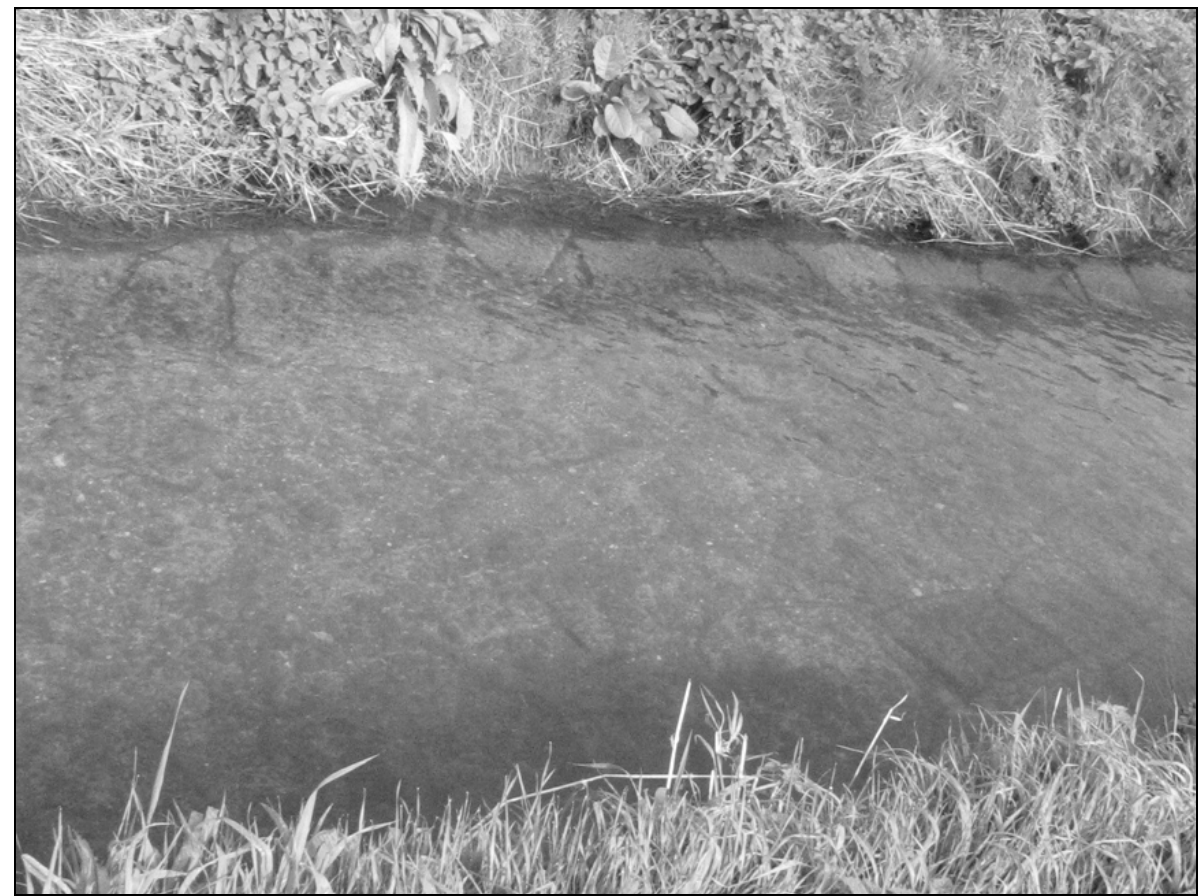

Figure 6: The paved bed of the "Urfahraner Sammelgerinne” in Linz before the restoration.

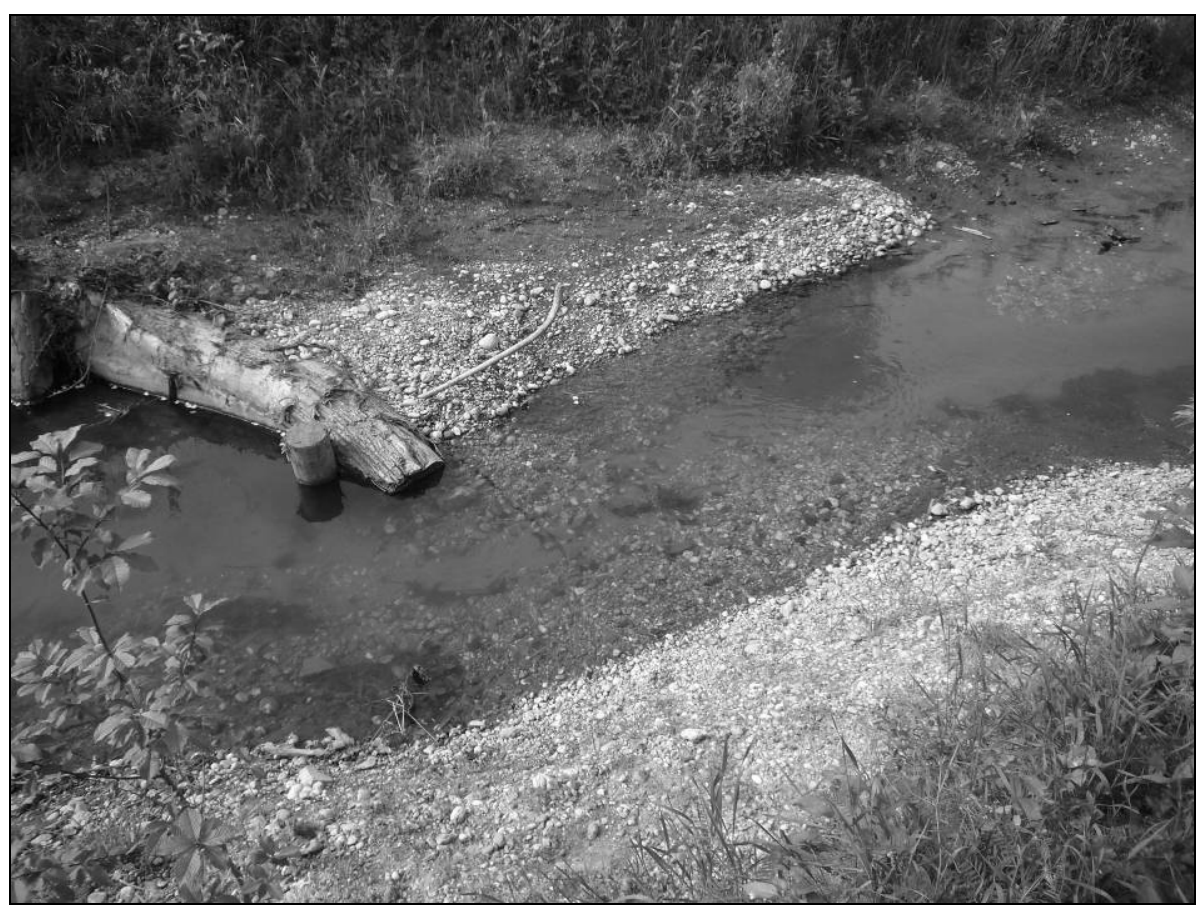

Figure 7: Nature-orientated bed of the "Urfahraner Sammelgerinne” in Linz after restoration. 


\section{Enhancement of the connection between water and riparian areas}

As broad active channels should be established in a first step when restoring a water course, enough space will then be available to enhance the connectivity between aquatic and riparian areas. Profiles should provide a small channel in which the entire discharge is transported during low water situations. The remaining shallow banks should be shaped with variable slopes and hollows that fill with water when the discharge increases, in order to enhance the possibility for the development of ecotones with precious habitats and ecological niches. These areas also offer important reproduction areas for the semi-aquatic fauna and other water-bound animals. The hollows in the banks are flooded during phases of slightly elevated water levels, and therefore they are subject to a constant changing. Such pioneer-areas are very rare and therefore scarce and valuable biotopes.

In urban areas there is hardly ever enough space for such a broad corridor, but the removal of the technical control structures and the structuring of the banks already improve the connectivity between the water course and its surroundings markedly.

\section{Increase of retention and flood protection}

Flood protection is one of the most important topics in urban areas. Due to the absence of natural expanded floodplains the potential of retention and infiltration is minimised. The increased sealing of the soil surface in urban areas intensifies this problem even more and causes extreme flooding.

In order to handle this problem effectively, the whole catchment area must be taken into account, because the occasion of extreme flooding results from the interaction of diverse factors. If that is not possible, at least the profile of the water course in the project area should be widened as largely as possible.

\section{DISCUSSION AND CONCLUSIONS}

The practical experience from restorations that have already been realised provides evidence of a positive ecological and dynamic development in quite a short period of time. Especially during higher discharges the inserted wooden elements fulfil their function as structures and habitats.

In order to quantify these improvements, monitoring should be carried out after each restoration project. On the one hand a monitoring helps to find the best way of construction for the respective types of running waters. On the other hand structure-improving is an important measure to fulfil the general objective of the WFD concerning the protection and improvement of water bodies and therefore needs to be measured. The WFD claims the good ecological and chemical status for all bodies of surface water and accordingly the good ecological potential for heavily modified or artificial water bodies until the year 2015 (European Commission, 2000). Due to that fact it is important to quantify the effects of a restoration on the ecological status. In the determination of the ecological status the proof of a typical community of fish species is the most important parameter in Austria. Fish reveal perfect indicator values for the hydro-morphology of a water course due to their mobility on the one hand and their dependency on structures on the other hand.

From the results of a monitoring basic guidelines for the restoration of urban water courses need to be deduced, because this field of work is still young and the experience quite short. Only by learning from each other's experience the complexity of aquatic ecosystems can be understood and strategies to restore and conserve them can be deduced. 


\section{REFERENCES}

1. European Commission, 2000 - Directive 2000/60/EC of the European Parliament and the Council of 23 October 2000 establishing a framework for Community action in the field of water policy, European Commission PE-CONS 3639/1/100 Rev 1, Luxembourg, 72.

2. Gumpinger C. and Scheder C., 2008 - Decline of biodiversity as a result of various impacts related to river regulation - exemplified by several small river catchments (Austria), Transylvanian Review of Systematical and Ecological Research, The Wetlands Diversity, 6, 141-148.

3. Ulmann P. and Peter A., 1994 - Ökotone und Biodiversität: Vernetzung von Fließgewässerlebensräumen - eine fischbiologische Perspektive, EAWAG - Literaturstudie, 75. (in German)

4. Zalewski M. and Wagner-Lotkowska I., 2004 - Integrated Watershed Management Ecohydrology and Phytotechnology, United Nations Environment Programme, 246. 